\title{
Kendali Robot Spray Disinfektan Otomatis
}

\section{YOSI APRIANI ${ }^{1}$, WIWIN ARMOLDO OKTAVIANI ANWAR ${ }^{2}$, ERTATI SUARNI ${ }^{3}$}

1,2Teknik Elektro Universitas Muhammadiyah Palembang, Indonesia ${ }^{3}$ Pendidikan Dokter Universitas Muhammadiyah Palembang, Indonesia Email: yosi_apriani@um-palembang.ac.id

Received 15 Februari 2021 | Revised 11 Maret 2021 | Accepted 3 Juni 2021

\begin{abstract}
ABSTRAK
Penyebaran Covid-19 dapat diminimalisir dengan bebeberapa cara diantaranya penyemprotan antiseptik. Tujuan penelitian ini menghasilkan robot yang berguna meminimalisir penyebaran Covid-19 dengan sistem kontrol otomatis menggunakan Arduino Uno R3 serta panel surya yang dikoneksikan dengan sistem IoT (Internet Of Things). Penelitian ini menggunakan metode penelitian yang terdiri dari empat tahapan: 1). Mendesain (merancang) alat, 2). Tahapan pembuatan alat, 3). Tahapan ujicoba alat, 4) Tahapan analisis alat. Ketika ada benda yang berada pada titik atau jarak tertentu maka sensor ultrasonik akan mendeteksinya dan akan mengirimkan sinyal ke mikrokontroler selanjutnya robot akan bekerja kembali seuai perintah dari android. Hasil pengujian saat ada obstacle dengan nilai $v=11,40$ Volt di dapat nilai acuan pengukuran dan nilai hasil pengkuruan memiliki nilai rentang error tertinggi pada saat nilai acuan 55 $\mathrm{cm}$ dan nilai hasil pengukuran $52 \mathrm{~cm}$. Pengujian RPM pada roda kiri posisi (maju) nilai tertinggi sebesar 40,0 RPM dan roda kanan 39,7 RPM.
\end{abstract}

Kata kunci: Arduino, robot, android, IoT, Covid-19, panel surya

\begin{abstract}
The spread of Covid-19 can be minimized in several ways, including spraying antiseptics. The purpose of this research is to produce a robot that is useful for minimizing the spread of Covid-19 with an automatic control system using Arduino Uno R3 and solar panels that are connected to the IoT (Internet Of Things) system. This study uses a research method consisting of four stages: 1). Designing (designing) tools, 2). Stages of making tools, 3). Stages of testing tools, 4) Stages of tool analysis. When there is an object that is at a certain point or distance, the ultrasonic sensor will detect it and will send a signal to the microcontroller then the robot will work again according to the command from the android. The test results when there is an obstacle with a value of $v=11.40$ Volts the measurement reference value is obtained and the measurement result value has the highest error range value when the reference value is $55 \mathrm{~cm}$ and the measurement value is $52 \mathrm{~cm}$. RPM testing on the left wheel position (forward) the highest value of 40.0 RPM and the right wheel 39.7 RPM.
\end{abstract}

Keywords: Arduino, robot, android, IoT, Covid-19, solar panels 
Kendali Robot Spray Desinfektan Otomatis

\section{PENDAHULUAN}

Wabah virus corona 2019 yang disingkat dengan Covid-19 adalah wabah penyakit berupa virus jenis baru yang pertama kali ditemukan di Wuhan, Hubei, China pada tahun 2019 (Setiawan, 2020) yang menginfeksi saluran pernapasan dan menyebabkan batuk, sesak nafas atau kesulitan bernafas, bahkan apabila manusia terjangkit virus ini bisa menyebabkan beberapa penyakit yang terkait pernapasan seperti pneumonia, sindrom pernapasan akut, gagal ginjal dan bahkan kematian (Djasri, 2020). Penularan Covid-19 terjadi dari orang ke orang di rumah atau di rumah sakit (Chan, dkk, 2020). Penyebarannya Covid-19 ini juga telah terjadi antar kota. Penularan bisa terjadi saat berinteraksi dengan orang yang menderita Covid-19, bahkan bisa tertular juga oleh sesorang yang merupakan penderita Covid-19 tetapi tanpa merasakan gejala, di mana setelah itu orang memegang mulut atau hidung tanpa mencuci tangan terlebih dulu setelah memegang benda yang terkena cipratan air liur penederita Covid-19, dan kontak jarak dekat dengan penederita Covid-19 (Dani, dkk, 2020), oleh sebab itu diperlukan langkah-langkah pengendalian virus untuk meminimalisir penyebarannya dan menghindari kejadian superspreading.

Salah satu dari sekian banyak cara yang bisa dilakukan untuk mencegah penularan wabah tersebut adalah sanitasi. Sanitasi dapat dilakukan dengan mencuci permukaan tubuh seperti mencuci muka dan tangan dengan teratur (Jin, dkk, 2020) (Doremalen, dkk, 2020). Menjaga imunitas tubuh, dengan cara mengonsumsi makanan sehat, kebersihan diri serta rumah dan lingkungan sekitar juga merupakan cara efektif mengurangi penyebaran wabah virus Covid-19 (Larasati, dkk, 2020). Penggunaan antiseptik dan disinfektan efektif untuk mencegah dan meminimalisir penularan Covid-19 bila dilakukan dengan cara yang tepat. Sementara antiseptik merupakan cairan yang mengandung zat yang dapat menghambat perkembangan dan pertumbuhan mikroorganisme tersebut tanpa membunuh mikroorganisme di jaringan hidup (Gargi, dkk, 2017). Cairan antiseptik yang terbukti efektif salah satunya yaitu cairan pencuci mulut dan semprotan hidung (Eggers, 2019). Berdasarkan kajian seperti yang diuraikan diatas maka dirasa perlu untuk untuk membuat suatu alat penyemprotan antiseptik yang mampu menyemprot secara otomatis tanpa membahayakan kesehatan.

Penelitian sebelumnya yang pernah meneliti penyemprot disinfektan menggunakan Arduino yaitu (Habibullah, 2020) yang menyatakan bahwa penyemprot yang dipakai menggunakan teknologi Arduino nano dan sensor nya menggunakan proximiti E-18-D80NK, hasil yang didapatkan alat bekerja dengan baik meskipun berada di dalam ruangan, alat bersifat statis (diam) yaitu berupa bilik disinfektan yang diujikan baik didalam ruangan maupun diluar ruangan. Penelitian lainnya yaitu (Trisetiyanto, 2020) yang menyatakan bahwa penyemprot disinfektan menggunakan kontroler Arduino uno, sensor yang dipakai menggunakan sensor ultrasonik, hasil penelitian yang didapatkan adalah berupa bilik disinfektan yang besifat statis (diam) yang menghasilkan hasil semprotan berupa kabut (embun). Alat akan bekerja saat ada objek yang melewati bilik disinfektan, baik itu objeknya manusia maupun kendaraan yang lewat. Penelitian (Trisetiyanto, 2020) ini meletakkan posisi sprayer di berbagai titik agar bisa menjangkau objek yang lewat di bilik. Penelitian lainnya yang meneliti kendali Arduino yaitu (Herkariawan, dkk, 2020) meneliti robot tempur otomatis menggunakan sistem kendali berupa gesture control berbasis Arduino nano. Remote yang digunakan adalah berupa android yang menggunakan teknologi IOT. Robot tempur ini menggunakan sensor accelometer untuk gesture kontrolnya. Hasil penelitian ini didapatkan kendali robot menggunakan sensor accelometer sehingga lebih mudah dalam mengoperasikan robot. 
Penelitian selanjutnya yaitu (Touni, dkk, 2020) yang menyatakan ada tiga jenis robot, yaitu robot industri, robot layanan profesional dan robot layanan pribadi. Salah satu contoh nya adalah robot Raisa yang ada di industri rumah sakit, misalnya robot Raisa yang bisa membersihkan atau mensterilkan lantai, dimana robot Raisa tersebut menggunakan teknologi Artificial Inteligence. Beberapa manfaat robot Raisa adalah penghematan biaya serta meningkatkan produktifitas di dunia kerja atau industri. Penelitian lainnya (Setiawan, dkk, 2020) menggunakan kontrol robot intai yang menggunakan smartphone melalui jaringan wi-fi. Robot ini dilengkapi kamera tersembunyi berupa video realtime yang dikirim ke android. Data yang diperoleh dikirimkan menggunakan Estimasi Signal to Noise Ratio dari robot intai ke android dengan metode korelasi.

Penelitian yang telah kami lakukan memanfaatkan kontrol Arduino yang dikoneksikan dengan IoT (Internet Of Things) melalui aplikasi Blynk yang di-instal di smartphone. Penelitian ini juga menggunakan panel surya sebagai sumber listrik untuk menggerakkan robotnya. Aplikasi Blynk berfungsi sebagai tombol perintah untuk memerintahkan robot penyemprot agar bekerja sesuai perintah manusia. Aplikasi Blynk juga memperlihatkan volume disinfektan yang berada di robot serta memberikan pesan atau notifikasi di android jika ada obstacle atau halangan di depan robot, selain itu juga memperlihatkan nilai "tegangan" yang terpasang di robot penyemprot saat sedang diaktifkan. Penelitian ini menghasilkan sebuah sistem robot penyemprot disinfektan yang bersifat mobile (bisa digerakkan) sesuai perintah manusia dari android. Pergerakkan robot juga bisa berputar balik sampai $360^{\circ}$. Hasil semprotan disinfektan adalah semprotan yang bersifat basah, bukan yang bersifat mist atau embun (kabut) seperti penelitian-penelitian sebelumnya.

\section{METODE PENELITIAN}

\subsection{Arduino dan IoT}

Sistem kontrol Arduino merupakan sistem kendali otomatis dimana nilai input dan nilai output-nya bisa disesuaikan dengan rancangan atau desain yang dikehendaki ( $\mathbf{L i}, \mathbf{2 0 1 9})$ (Ardianto, dkk, 2019) (Rijalusalam, dkk, 2021). Suatu sistem kontrol otomatatis merupakan sistem yang memiliki cara kerja mengendalikan proses suatu kerja tanpa adanya campur tangan manusia (Erinofiardi, dkk, 2012) (Irawan, dkk, 2021). Arduino merupakan sistem kontrol yang terdiri dari software dan hardware. Arduino merpakan pusat kendali utama keseluruhan sistem. sama dengan mikrocontroller pada umumnya hanya saja terdapat penamaan pin pada Arduino agar mudah diingat karena Arduino sebagai pusat kendali utama keseluruhan sistem seperti terlihat di Gambar 1.

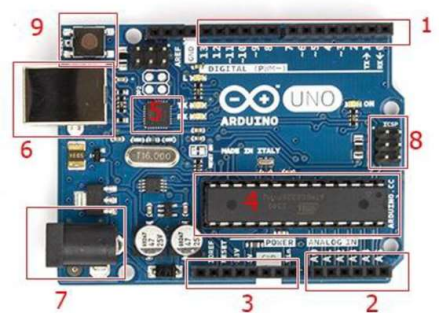

Gambar 1. Arduino Uno

IoT (Internet Of Things) merupakan suatu sistem perangkat yang bisa mentransfer data dengan menggunakan media internet. IoT ini memiliki Cloud Data Center yang berfungsi tempat menyimpan aplikasi dan database (Wardiyanto, dkk, 2018). 


\subsection{BMS dan Lithium Battery}

Battery Management System (BMS) bekerja untuk charging pada baterai yang dilengkapi kemampuan untuk mendeteksi level arus yang ada dan menentukan kapasitas pengisian baterai sehingga pengisian baterai menjadi balance berdasarkan kebutuhan tiap cell. BMS bisa terlihat seperti Gambar 2 (Raghavendra, dkk, 2018). BMS juga dilengkapi fungsinya untuk cutt off jika level tegangan mencapai nilai tertentu maka tidak akan di supply lagi.

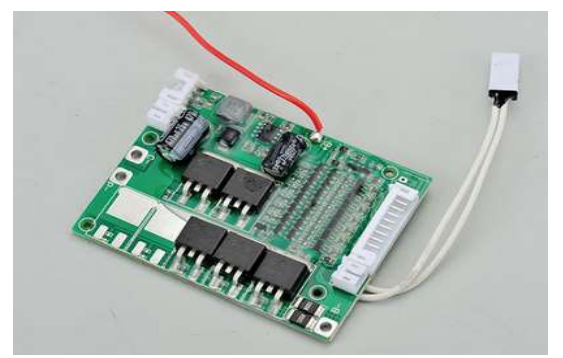

\section{Gambar 2. Battery Management System (BMS)}

\subsection{Perancangan Sistem}

Pada tahapan pertama dirumuskan analisis kebutuhan dari perancangan sistem Arduino uno sebagai kendali robot spray disinfektan otomatis. Arduino Uno R3 dan panel surya yang merupakan pengendali dari sistem robot ini akan menggunakan IOT (Internet Of Things) yang dirancang untuk meminimalisir penyebaran Covid-19. Gambar 3 berikut ini merupakan desain alat penyemrotan antiseptik disinfektan yang dibangun melalui sistem kontrol otomatis.

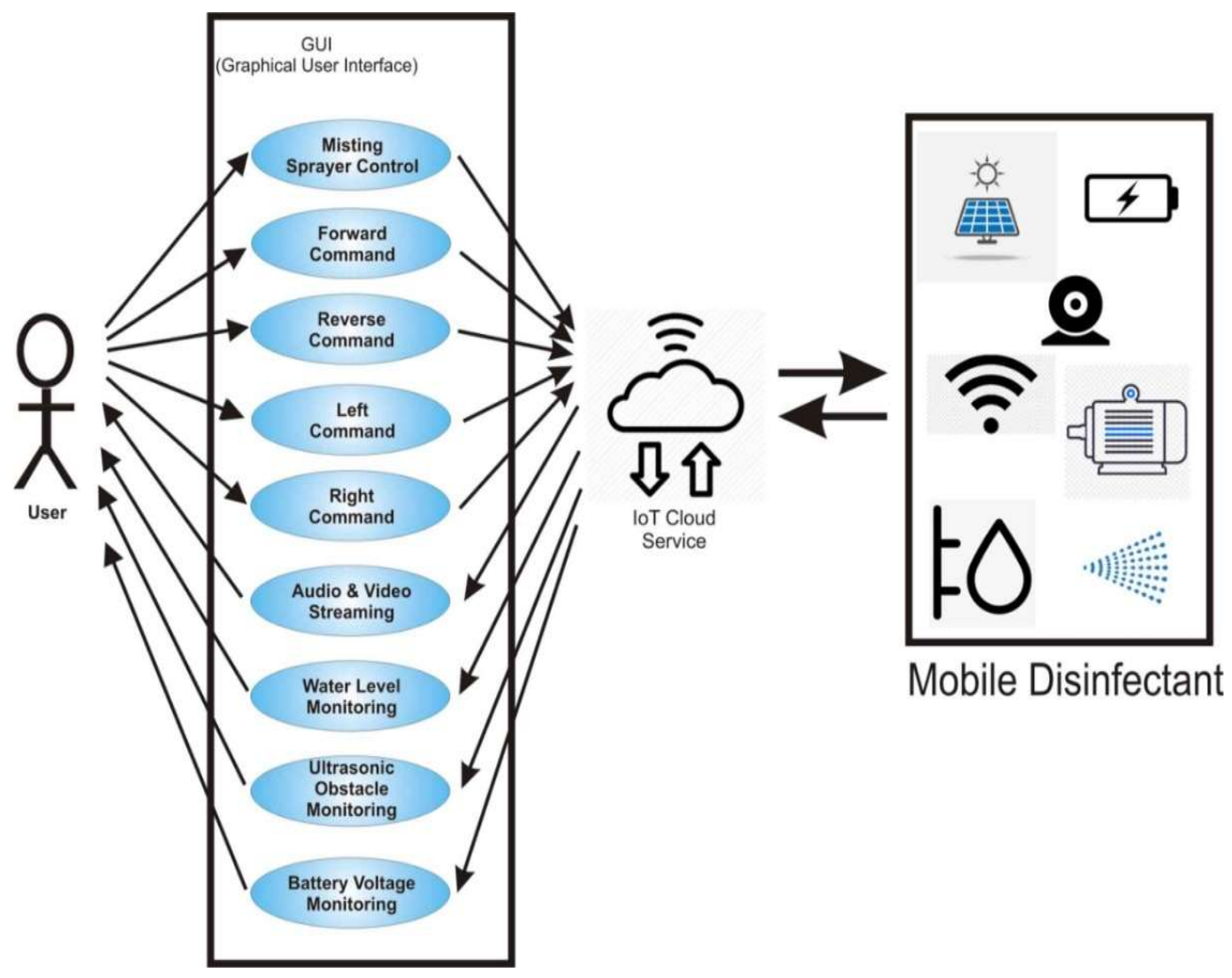

Gambar 3. Gambaran Umum Sistem Robot Penyemprot Disinfektan 


\subsection{Proses Desain Alat}

Pada tahap awal alat dikoneksikan dengan panel surya yang menjadi sumber energi untuk robot penyemprot. Alat Penyemprotan antiseptik ini didesain menggunakan Arduino dengan input sensor ultrasonic HC-SR04. Arduino juga dikoneksikan dengan IoT sebagai penyimpan database. Wiring diagram dari robot penyemprot disinfektan terlihat pada Gambar 4.

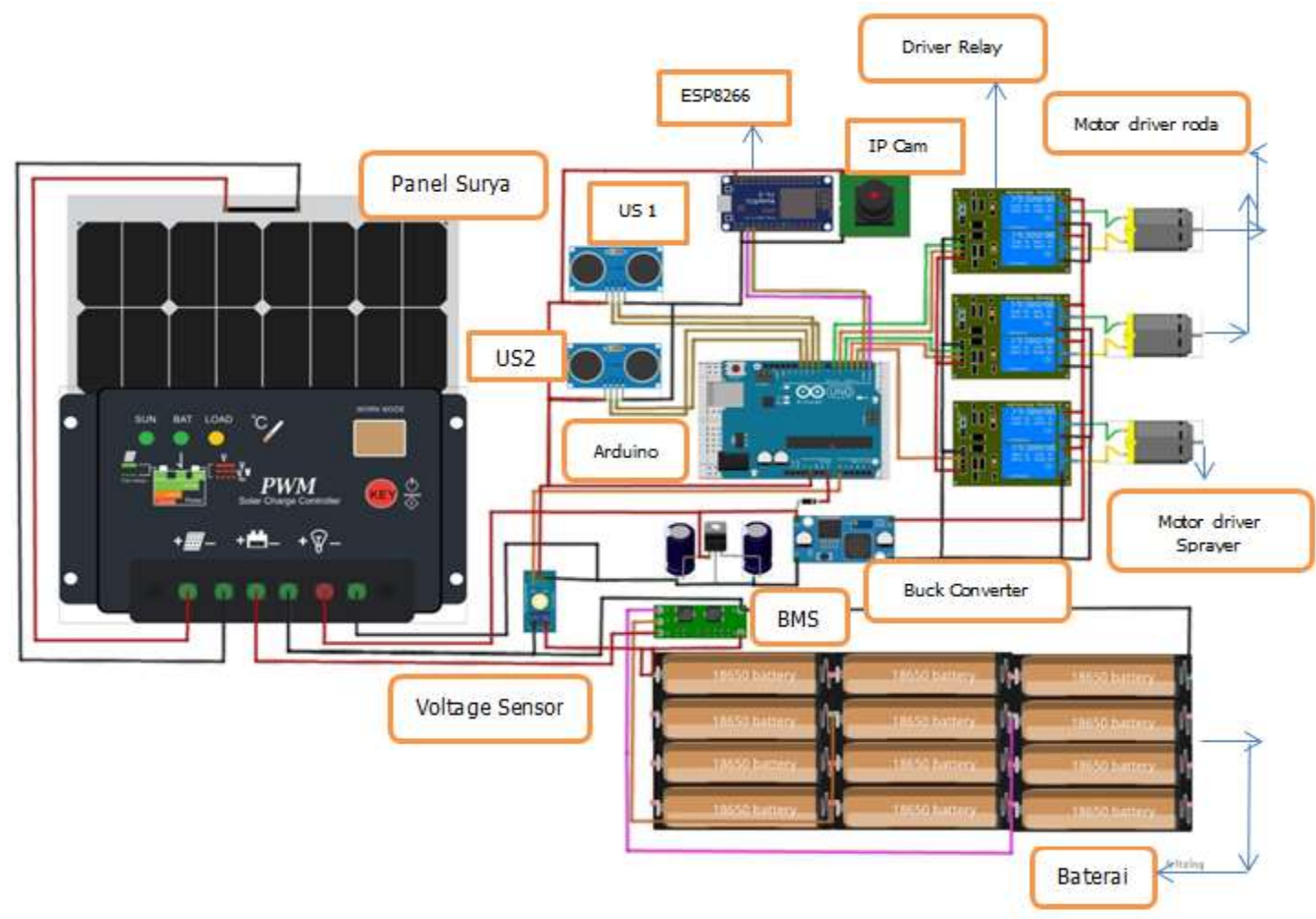

\section{Gambar 4. Wiring Diagram Robot Penyemprot Disinfektan}

Penyemprot disinfektan ini juga menggunakan BMS yang dapat mengontrol baterai yang mendapat supply energi dari panel surya. Selanjutnya output dari alat ini adalah Modul Relay $12 \mathrm{~V}$ yang berfungsi menjalankan pompa dan output yang kedua adalah tampilan indikator pada android karena android yang berfungsi sebagai indikator proses penyemprotan yang sedang berlangsung. Pada tampilan android akan terlihat volume dari tangki disinfektan, serta akan tampil pula perintah-perintah untuk menjalankan robot penyemprot yang terdiri dari (kiri, kanan, depan, belakang). Alat ini menggunakan Nozze/ sebagai aperture yang berfungsi menghasilkan semprotan basah dari robot penyemprot. Serta yang utama adalah cairan anti disinfektan sebagai bahan baku sterilisasi. Gambar 5 adalah diagram alat yang memperlihatkan bagaimana robot penyemprot disinfektan ini bekerja.

Pada Gambar 5 terlihat bahwa sebelum robot mulai beroperasi ada beberapa tahapan yang harus dilewati. Pertama diawali dengan mengaktifkan wi-fi untuk terhubung ke server, setelah itu cek konektivitas apakah sudah terhubung atau belum. Tahapan selanjutnya adalah mengecek IP camera dan input perintah, IP camera disini berfungsi untuk memonitoring jarak jauh agar user (manusia) dapat berinteraksi dengan area lingkungan kerja robot. Akses yang digunakan dalam input perintah yaitu ada perintah : maju, mundur, depan, belakang. Tahapan selanjutnya mulai berikan perintah pada robot, jika terdapat halangan (obstacle) di depan pada jarak $60 \mathrm{~cm}$, maka robot akan mendeteksi lalu berhenti 
bergerak, kemudian mengirimkan pesan atau notifikasi ke android tetapi robot tetap melakukan penyemprotan. Jika pada saat bergerak tidak dideteksi adanya obstacle maka robot akan terus bergerak dan juga menyemprot.

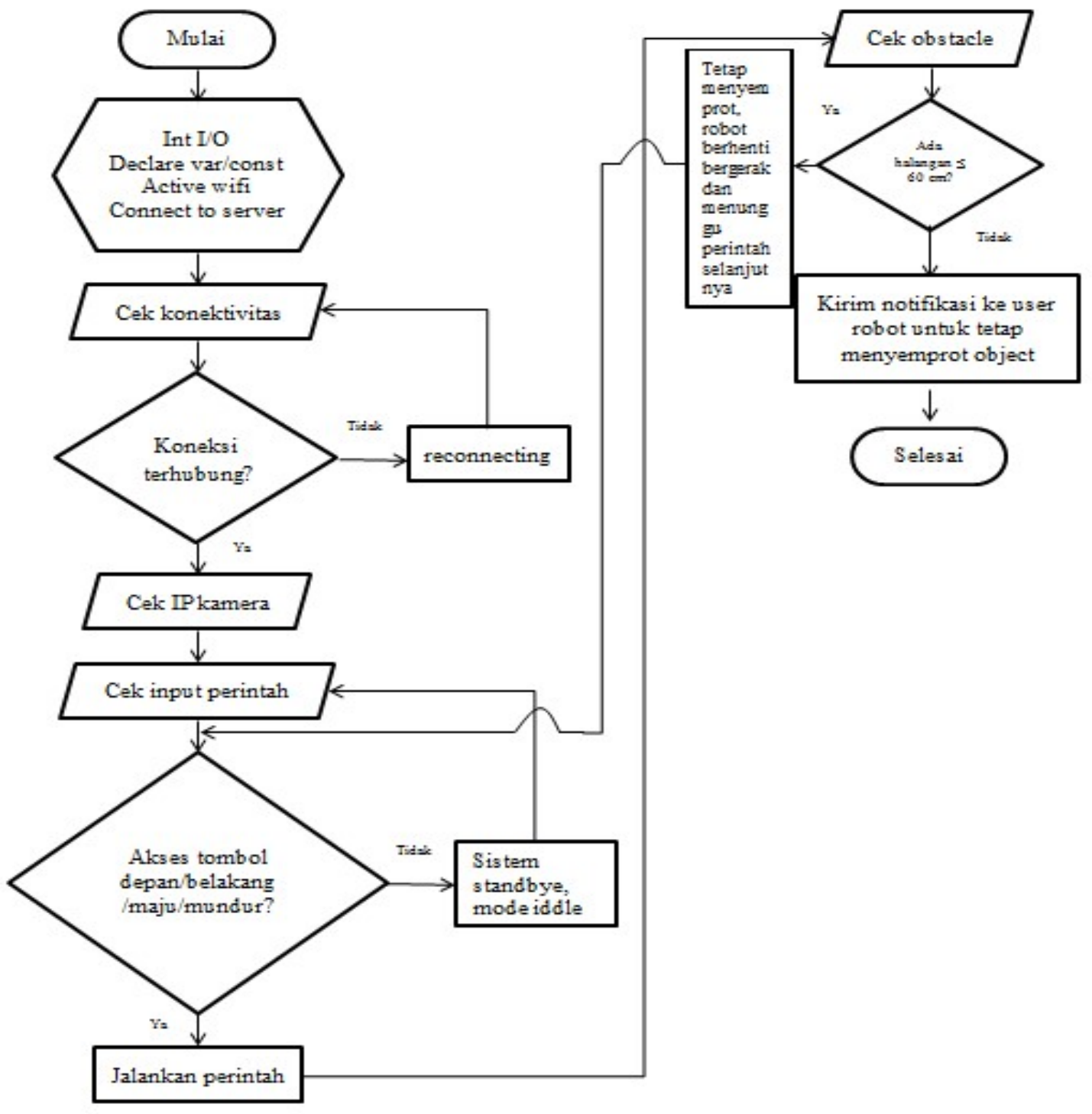

Gambar 5. Diagram Alir Cara Kerja Alat Keseluruhan

\section{HASIL DAN PEMBAHASAN}

\subsection{Hasil Perancangan Robot Penyemprot Disinfektan}

Setelah dilakukan perancangan sistem keseluruhan dari mulai pengoneksian dengan panel surya lalu terhubung ke baterai lithium yang terletak dibagian bawah robot dimana baterai berfungsi sebagai storage dari hasil produksi panel surya. Selanjutnya terkoneksi ke Arduino sebagai otak dari robot penyemprot disinfektan, sehingga alat bisa bekerja sesuai perintah dari android yang terkoneksi ke Arduino melalui sistem IoT. Dari Gambar 6 terlihat bahwa robot secara keseluruhan, dimana pada bagian depan robot terdapat IP camera yang berfungsi untuk memonitor jarak jauh agar user dapat berinteraksi dengan kondisi 
lingkungan kerja robot disinfektan. Terdapat juga sensor ultrasonic satu dan sensor ultrasonic kedua yang masing-masing berfungsi sebagai sensor pendeteksi adanya obstacle dan sensor level cairan. Pada bagian atas robot terdapat panel surya sebagai sumber listrik robot. Bagian bawah robot terdapat baterai yang berfungsi sebagai penyimpan energi. Bagian belakang robot terdapat selang pipa penyemprot yang memiliki 4 titik semprot yang posisinya berada diatas box Arduino, MBS, buck converter. Gambar rangkaian keseluruhan dapat dilihat seperti Gambar 6.

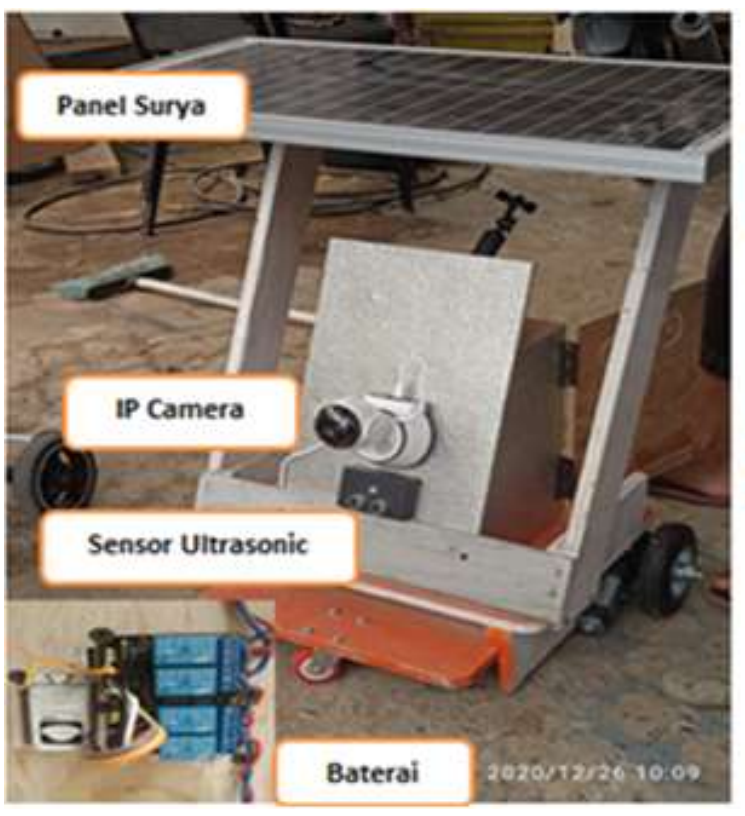

(a)

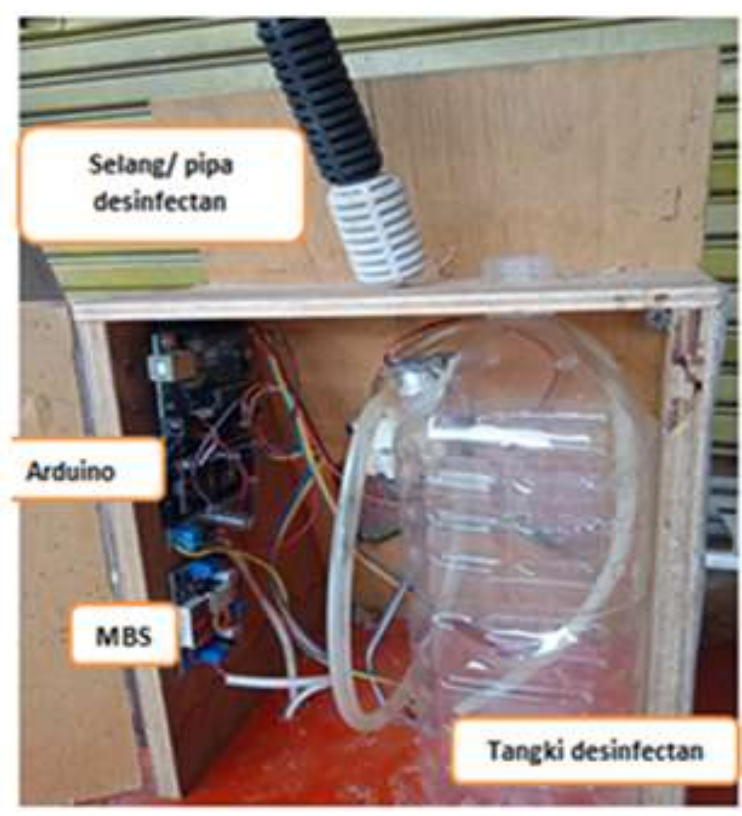

(b)

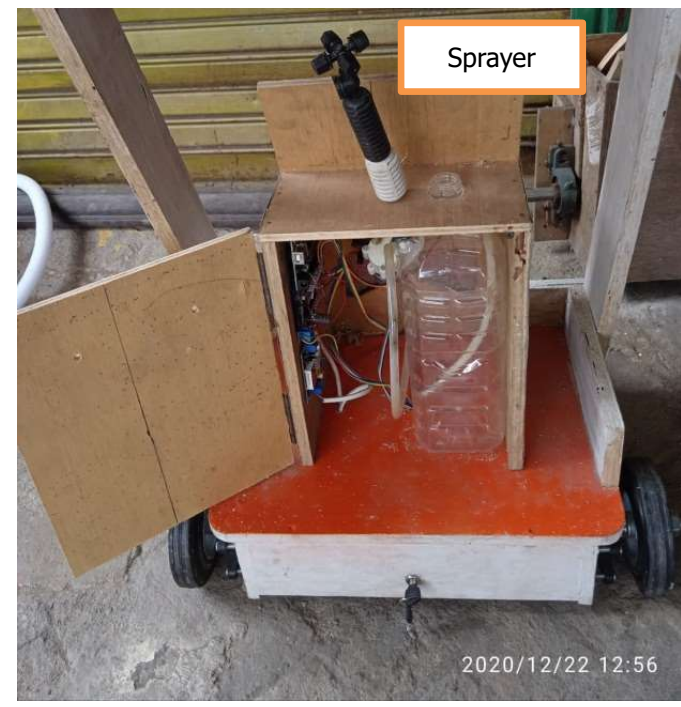

(c)

Gambar 6. (a) Tampak Depan Robot, (b) Tampak Belakang Robot (c) Arah Selang Disinfektan 4 Titik Semprot 
Bagian belakang robot terdapat selang pipa penyemprot yang memiliki 4 titik semprot yang posisinya berada diatas box Arduino, MBS, buck converter. Robot juga bisa berputar $360^{\circ}$ selama proses penyemprotan. Gambar 7 memperlihatkan tampilan robot saat proses penyemprotan.
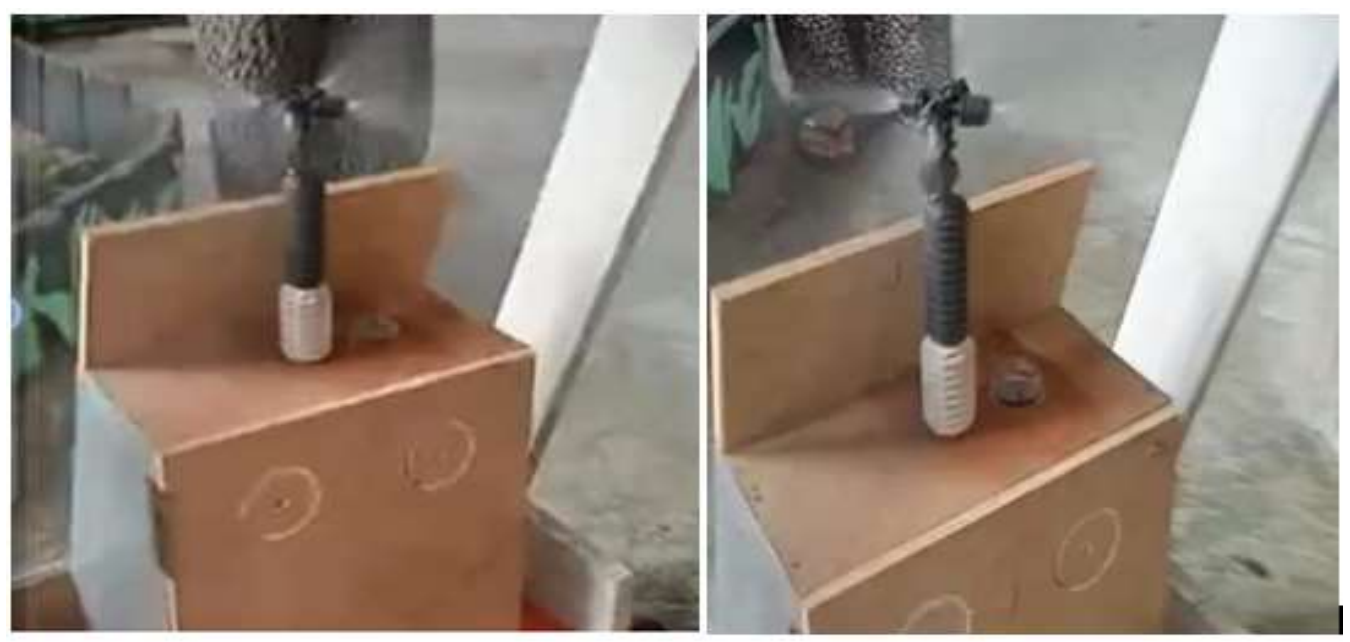

Gambar 7. Tampilan Robot pada Saat Proses Penyemprotan

\subsection{Hasil Pengujian Obstacle dengan V=11, 40 Volt}

Dari hasil pengukuran obstacle dengan jarak yang paling minimum sampai jarak maksimum $100 \mathrm{~cm}$ didapatkan perbedaan hasil pengukuran dengan titik acuan tidak begitu besar, dengan rentang error dari 0 sampai dengan 3. Hal ini bisa diartikan bahwa hasil pengukuran telah mendekati titik acuan perhitungan seperti terlihat pada Tabel 1.

\section{Tabel 1. Hasil Pengukuran Penyemprot dengan Obstacle}

\begin{tabular}{|c|c|c|c|}
\hline No & $\begin{array}{c}\text { Acuan Pengukuran } \\
(\mathbf{c m})\end{array}$ & $\begin{array}{c}\text { Hasil Pengukuran } \\
(\mathbf{c m})\end{array}$ & E \\
\hline 1 & 10 & 10 & 0 \\
\hline 2 & 15 & 15 & 0 \\
\hline 3 & 20 & 19 & 1 \\
\hline 4 & 25 & 24 & 1 \\
\hline 5 & 30 & 28 & 2 \\
\hline 6 & 35 & 34 & 1 \\
\hline 7 & 40 & 38 & 2 \\
\hline 8 & 45 & 43 & 2 \\
\hline 9 & 50 & 47 & 3 \\
\hline 10 & 55 & 52 & 3 \\
\hline 11 & 60 & 59 & 1 \\
\hline 12 & 65 & 64 & 1 \\
\hline 13 & 70 & 68 & 2 \\
\hline 14 & 75 & 73 & 2 \\
\hline 15 & 80 & 78 & 2 \\
\hline 16 & 85 & 83 & 2 \\
\hline 17 & 90 & 89 & 1 \\
\hline 18 & 95 & 94 & 1 \\
\hline 19 & 100 & 100 & 0 \\
\hline
\end{tabular}




\subsection{Hasil Tampilan Blynk (Aplikasi Remote Kontrol) di Android}

Gambar 8 berikut ini merupakan tampilan pada android yang terhubung ke sistem robot penyemprot disinfektan. Kondisi tampilan diambil pada saat pengukuran obstacle dengan jarak $11 \mathrm{~cm}, 50 \mathrm{~cm}$. Dari tampilan Blynk terlihat bahwa tegangan yang dihasilkan cenderung stabil berkisar antara $11,43 \mathrm{~V}$ sampai dengan $11,45 \mathrm{~V}$, hasil tersebut di dapatkan dari pengukuran dengan jarak obstacle yang paling dekat yaitu $11 \mathrm{~cm}$ sampai ke jarak $50 \mathrm{~cm}$ dimana pada jarak $11 \mathrm{~cm}$ sampai $100 \mathrm{~cm}$ robot akan mengambil keputusan untuk berhenti bergerak tetapi tetap menyemprot, dan menunggu perintah selanjutnya dari android. Pada Gambar 8 ini juga terlihat bahwa level cairan terdekteksi dengan posisi ON di tombol Noozle. Sedangkan Gambar 9 adalah tampilan Blynk saat ada obstacle di depan robot disinfektan.

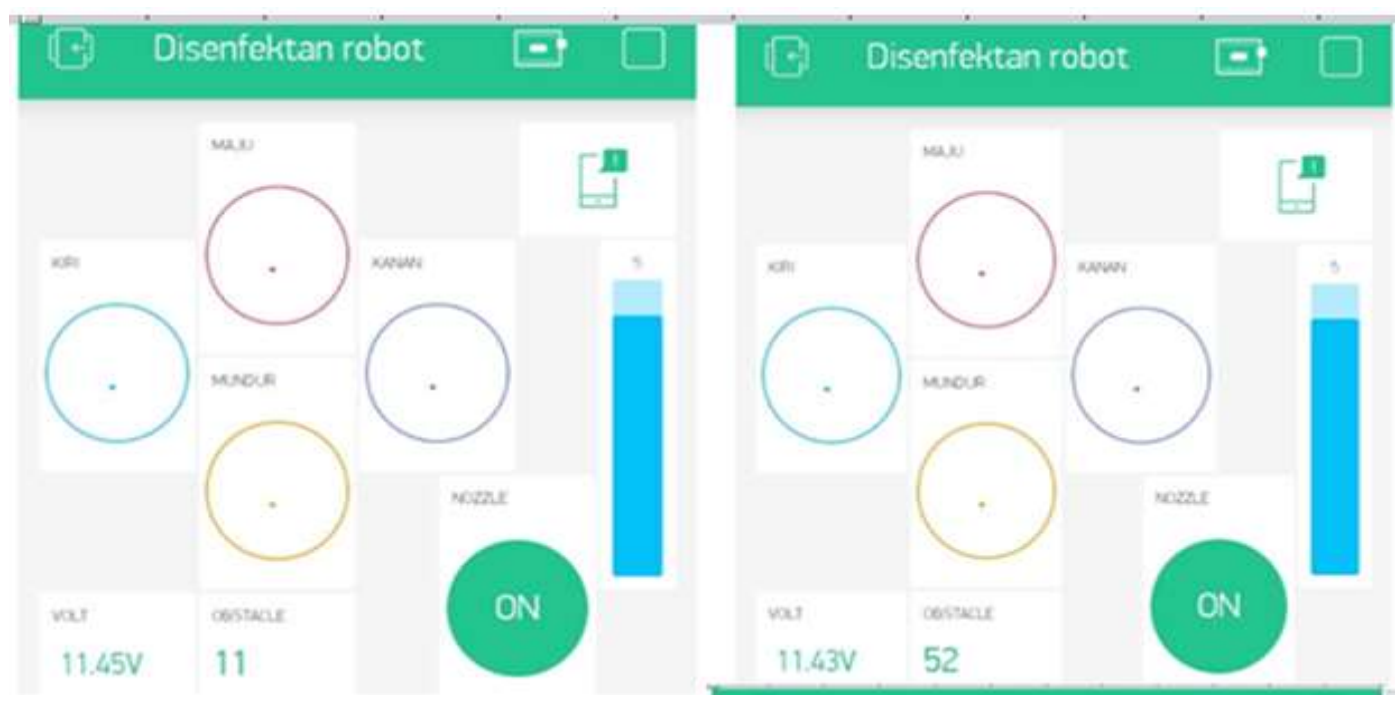

Gambar 8. Tampilan B/ynk di Android pada Saat Robot Mengambil Keputusan untuk Berhenti Bergerak karena terdapat Obstacle Jarak Dekat

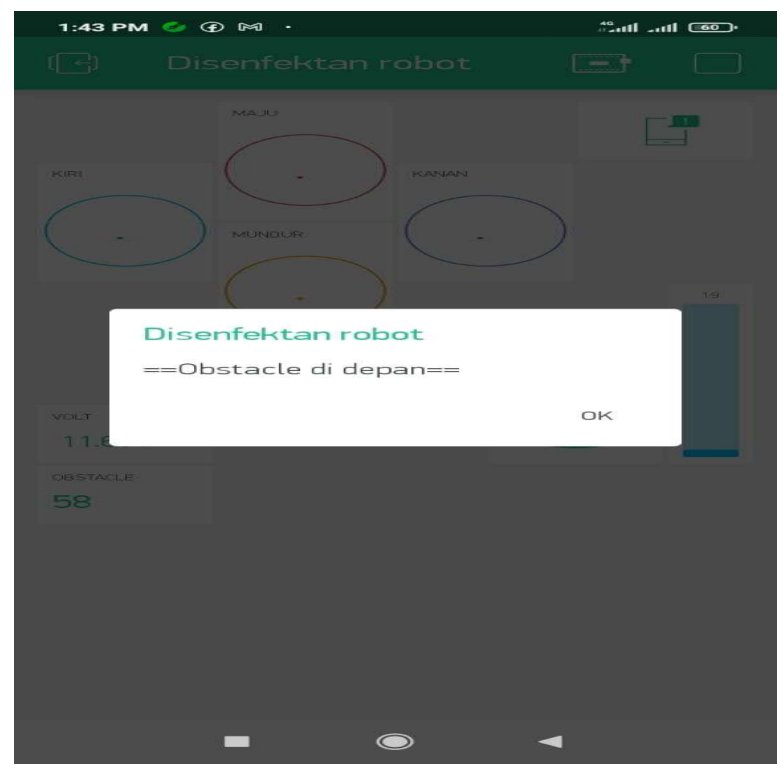

Gambar 9. Tampilan Blynk saat Mendapat Notifikasi dari Sensor Ultrasonik Saat Ada Obstacle 
Pada Gambar 10 memperlihatkan tampilan Blynk pada saat robot mendapatkan perintah maju, mundur, kiri atau kanan dimana di depan robot terdeteksi bahwa tidak ada halangan atau halangan masih sangat jauh posisinya.

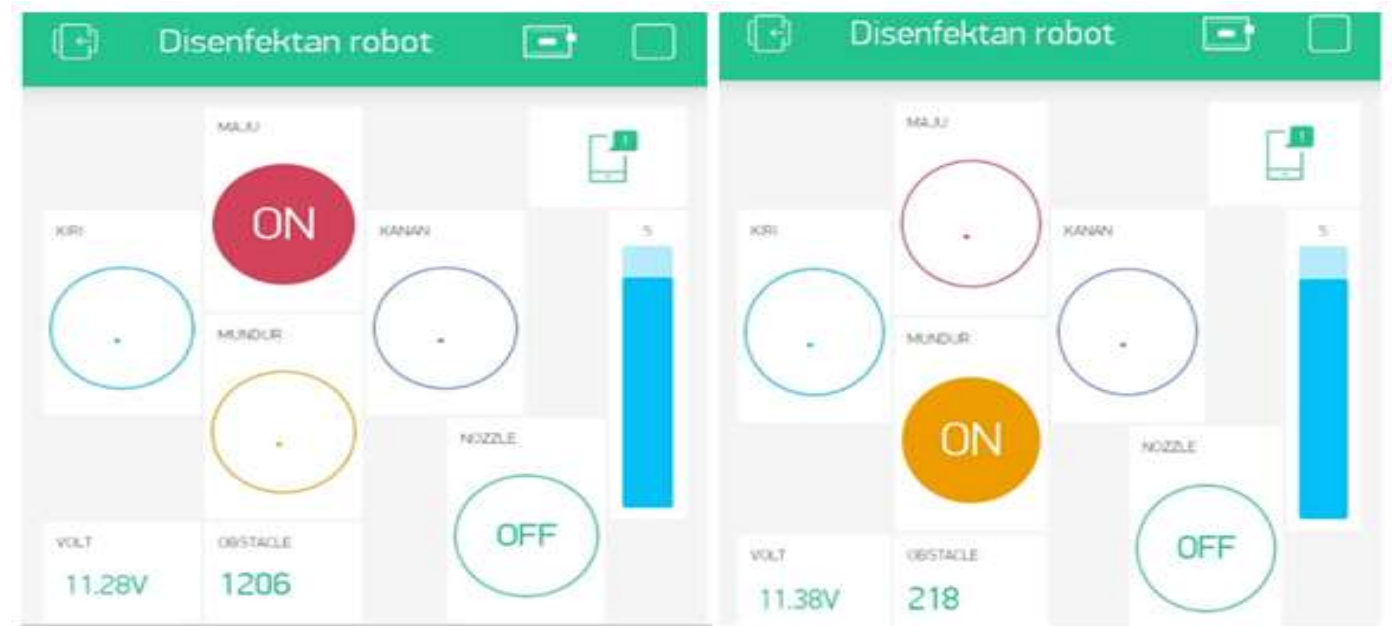

Gambar 9. Tampilan Blynk di Android Saat Robot Mendapat Perintah Maju dan Mundur

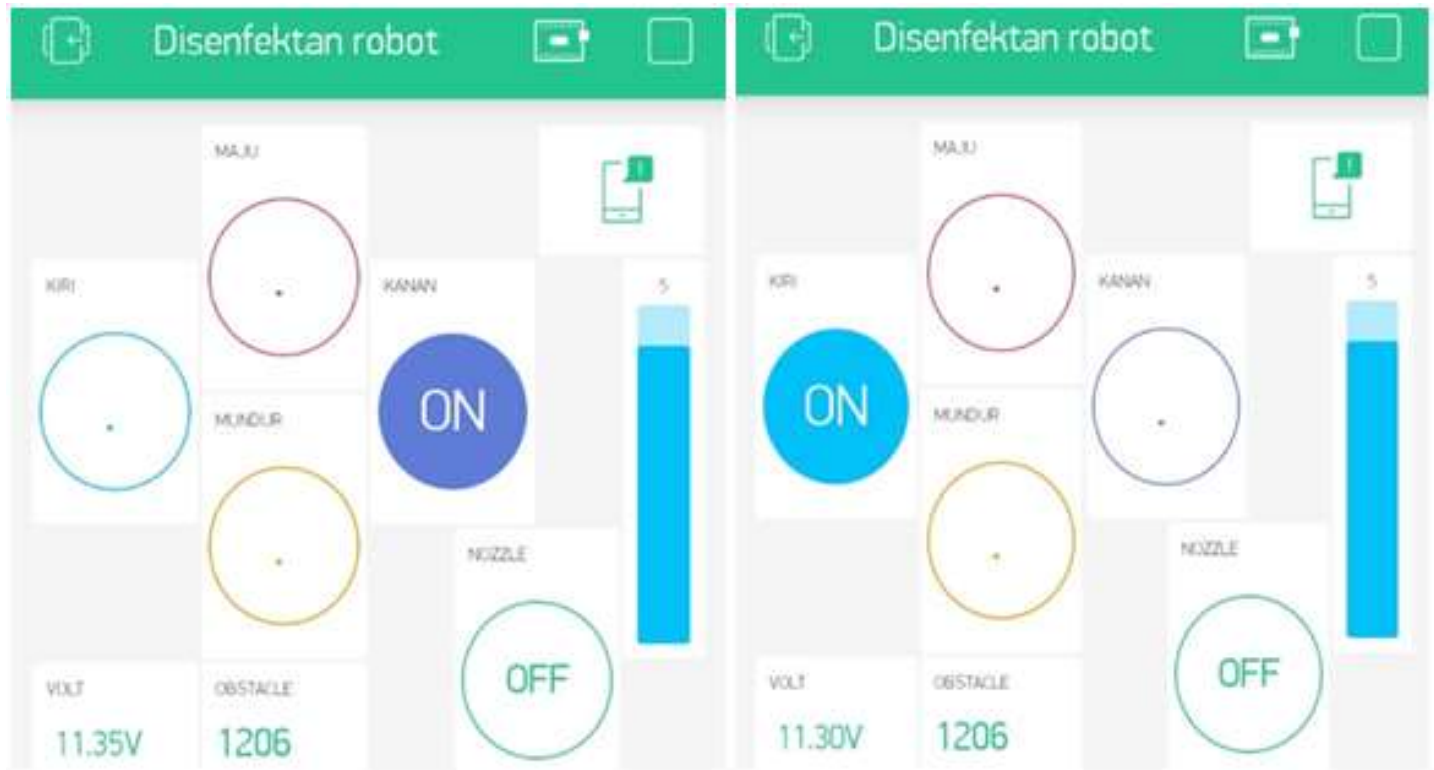

Gambar 10. Tampilan Blynk di Android pada Saat Robot Mendapat Perintah Kanan dan Kiri

\subsection{Hasil Pengukuran RPM pada Roda Robot Penyemprot}

Pada pengukuran RPM pada setiap roda penyemprot didapatkan seperti pada Tabel 2, dimana didapatkan putaran roda kiri berkisar 39.8 sampai dengan 40.0 RPM untuk posisi perintah "maju". Sedangkan untuk roda kanan pada posisi perintah "maju" berkisar antara 39.5 sampai 39.9. Pada posisi perintah "mundur" di roda kiri didapat RPM berkisar antara 39.2 sampai dengan 39.9, sedangkan di roda kanan didapatkan nilai RPM sebesar 39.2 sampai 39.5. RPM untuk posisi perintah ke "kiri" roda kiri bernilai nol, sedangkan roda kanan RPM nya bernilai 39.2 sampai 39.8. Pada mode perintah ke "kanan" roda kanan bernilai nol dan roda kiri bernilai 38.9 sampai 40.4 . 
Tabel 2. Hasil Pengukuran RPM pada Setiap Roda Robot Penyemprot Disinfektan

\begin{tabular}{|l|l|c|c|}
\hline No & \multicolumn{2}{|c|}{ Mode Perintah } & RPM \\
\hline 1 & \multirow{2}{*}{ Maju } & Roda kiri & $39.8 ; 39.8 ; 39.9 ; 39.8 ; 40.0$ \\
\cline { 3 - 4 } & & Roda kanan & $39.5 ; 39.7 ; 39.5 ; 39.9 ; 39.7$ \\
\hline 2 & \multirow{2}{*}{ Mundur } & Roda kiri & $39.2 ; 39.3 ; 39.9 ; 39.7 ; 39.9$ \\
\cline { 3 - 4 } & & Roda kanan & $39.2 ; 39.3 ; 39.2 ; 39.5 ; 39.4$ \\
\hline \multirow{2}{*}{3} & \multirow{2}{*}{ Kiri } & Roda kiri & 0 \\
\hline \multirow{2}{*}{4} & & Roda kanan & $39.2 ; 39.6 ; 39.5 ; 39.6 ; 39.8$ \\
\cline { 3 - 4 } & & Roda kiri & $40.3 ; 40.1 ; 40.4 ; 40.3 ; 38.9$ \\
\cline { 2 - 4 } & & Roda kanan & 0 \\
\hline
\end{tabular}

Tabel 3. Hasil Pengujian Tegangan Referensi dan Laju Semprot Robot

\begin{tabular}{|c|c|c|c|}
\hline No & Kondisi Robot & $\begin{array}{c}\text { Tegangan Referensi } \\
\text { (Volt) }\end{array}$ & $\begin{array}{c}\text { Laju Semprot Tangki } \\
\text { (menit) }\end{array}$ \\
\hline 1 & On & 11.30 & 3 menit 35.52 detik \\
\hline 2 & Off & 11.38 & 3 menit 35.52 detik \\
\hline
\end{tabular}

\subsection{Pengukuran Tegangan Referensi dan Laju Semprot}

Hasil pengukuran tegangan referensi di dapatkan $\mathrm{V}$ referensi yang stabil yaitu sebesar 11.38 $\mathrm{V}$ saat keadaan robot Off dan $11.30 \mathrm{~V}$ saat keadaan robot $O n$, terlihat bahwa tegangan referensi cenderung stabil meskipun robot dalam keadaan On maupun Off. Sedangkan laju semprot untuk tangki dengan muatan 1.5 liter adalah sebesar 03 menit 35.52 detik. Waktu laju semprot tangki robot cenderung sama saat robot dalam kondisi On dan Off. Hasil pengukuran tegangan referensi dan laju semprot robot dapat dilihat pada Tabel 3 .

\section{KESIMPULAN}

Berdasarkan hasil penelitian, pengukuran serta analisis yang sudah dilakukan dapat dibuat kesimpulan bahwa sistem Arduino uno sebagai kendali robot spray disinfektan otomatis telah berhasil di buat sesuai dengan rancangan alat yang telah di desain pada tahap awal penelitian. Ketika terdapat obstacle di depan robot penyemprot maka robot yang telah memiliki IP cemera melalui sensor ultrasonik akan mendeteksinya dan mengirim notifikasi ke android. Hasil pengujian saat adanya obstacle nilai acuan pengukuran dan nilai hasil pengkuruan memiliki nilai rentang error tertinggi pada saat nilai acuan $55 \mathrm{~cm}$ dan nilai hasil pengkuran $52 \mathrm{~cm}$. Pengujian RPM pada roda kiri perintah (maju) nilai tertinggi sebesar 40.0 RPM dan roda kanan 39.7 RPM. Nilai RPM perintah (kiri) pada roda kanan 39.8 RPM dan roda kiri 0. Perintah (kanan) nilai RPM roda kiri 48.4 RPM dan roda kanan 0.

\section{UCAPAN TERIMA KASIH}

Tim peneliti mengutarakan terimakasih yang sebesarnya kepada Majelis DIKTILITBANG Pusat Muhammadiyah yang telah membiayai penelitian ini sampai dengan selesai dengan Surat Kontrak Penelitian Pendanaan dan Pelaksanaan Hibah RisetMU Skema Covid-19 tahun 2020, Nomor 0887.063/1.3/D/2020. 


\section{DAFTAR RUJUKAN}

Ardianto, F., Eliza, \& Saputra, R. (2019). Pendeteksi Pemakaian Beban Listrik Rumah Tangga. Jurnal Surya Energy, 4(1), 338-344.

Chan, J. F. W., Yuan, S., Kok, K. H., To, K. K. W., Chu, H., Yang, J., \& Yuen, K. Y. (2020). A familial cluster of pneumonia associated with the 2019 novel coronavirus indicating person-to-person transmission: a study of a family cluster. The Lancet, 395(10223), 514-523.

Dani, J. A., \& Mediantara, Y. (2020). Covid-19 dan Perubahan Komunikasi Sosial. Persepsi: Communication Journal, 3(1), 94-102.

Djasri, H. (2020). Corona Virus dan Manajemen Mutu Pelayanan Klinis di Rumah Sakit. The Journal of Hospital Accreditation, 2(1), 1-2.

Doremalen, N. V, Bushmaker, T., Morris, D. H., Olbrook, M. G., Gamble, A., Williamson, B. N., Tamin, A., Harcourt, J. L., Thornburg, N. J., Gerber, S. I., Jo, L. S., Wit, E. D., \& Munster, V. J. (2020). Aerosol and Surface Stability of SARS-CoV-2 as Compared with SARS-CoV-1. The New England Journal of Medicine, 382(16), 1564-1567.

Eggers, M. (2019). Infectious Disease Management and Control with Povidone Iodine. Infectious Diseases and Therapy, 8(4), 581-593.

Erinofiardi, Supardi, N. I., \& Redi. (2012). Penggunaan PLC dalam Pengontrolan Temperatur, Simulasi pada Prototype Ruangan. Jurnal Mekanikal, 3(2), 261-268.

Gargi, R., Vanmali, H. S., \& Jadhav, R. N. (2017). Efficacy study of some antiseptics and disinfectants. Int. J. of Life Sciences, 5(4), 593-598.

Habibullah, M. H. (2020). Desain Dan Implementasi Sensor Untuk Penyemprotan. Tesis Program Studi Teknik Elektro Universitas Muhammadiyah Surakarta.

Herkariawan, C., Muda, N. R. S., \& Minggu, D. (2020). Rancang Bangun Sistem Kendali Menggunakan Gesture Control Pada Robot Tempur Penyemprot Disinfektan Berbasis Arduino. Jurnal Telkommil, 1(2), 1-7.

Irawan, Y., Muhardi, M., Ordila, R., \& Diandra, R. (2021). Automatic Floor Cleaning Robot Using Arduino and Ultrasonic Sensor. Journal of Robotics and Control (JRC), 2(4), 4 7.

Jin, Y. H., Cai, L., Cheng, Z. S., Cheng, H., Deng, T., Fan, Y. P., Wang, X. H. (2020). A rapid advice guideline for the diagnosis and treatment of 2019 novel coronavirus (2019$\mathrm{nCoV}$ ) infected pneumonia (standard version). Medical Journal of Chinese People's Liberation Army, 45(1), 1-20.

Larasati, A. L., Gozali, D., \& Haribowo, C. (2020). Penggunaan Desinfektan dan Antiseptik 
Pada Pencegahan Penularan Covid-19 di Masyarakat. Majalah Farmasetika, 5(3), 137-145.

Li, J. H. (2019). Control System Laboratory With Arduino. Proceedings - 2018 International Symposium on Computer, Consumer and Control, IS3C 2018, (pp. 181-184).

Raghavendra, N. K., \& Padmavathi, K. (2018). Solar Charge Controller for Lithium-Ion Battery. Proceedings of 2018 IEEE International Conference on Power Electronics, Drives and Energy Systems, PEDES 2018, (pp. 1-5).

Rijalusalam, D. U., \& Iswanto, I. (2021). Implementation Kinematics Modeling and Odometry of Four Omni Wheel Mobile Robot on The Trajectory Planning and Motion Control Based Microcontroller. Journal Robotics and Control, 2(5), 448-455.

Setiawan, D., Syafaat, M., \& Setiawan, A. (2020). Sistem Estimasi Signal To Noise Ratio Untuk Komunikasi Data Dari Robot (Omniwee) Ke Android Dengan Menggunakan Metode Korelasi. Jurnal Elkasista, Vol.1, 5-13.

Setiawan, A. R. (2020). Lembar Kegiatan Literasi Saintifik untuk Pembelajaran Jarak Jauh Topik Penyakit Coronavirus 2019 (COVID-19). Edukatif: Jurnal IImu Pendidikan, 2(1), 28-37.

Touni, R., \& Magdy, A. (2020). The application of Robots, Artificial Intelligence, and Service Automation in the Egyptian Tourism and Hospitality Sector (Possibilities, Obstacles, Pros, and Cons). Journal of Association of Arab Universities for Tourism and Hospitality, 19(3), 269-290.

Trisetiyanto, A. N. (2020). Rancang Bangun Alat Penyemprot Disenfektan Otomatis untuk Mencegah Penyebaran Virus Corona. Journal of Informatics Education, 3(1), 45-51.

Wardiyanto, M. F., \& Yundra, E. (2018). Pengembangan Trainer Kit Mikrokontroller Arduino Uno Berbasis Iot Sebagai Media Penunjang Pembelajaran Pada Mata Pelajaran Sistem Kontrol Terprogram Di Smk Negeri 1 Jenangan Ponorogo. Jurnal Pendidikan Teknik Elektro, $8(1), 139-148$. 